ISSN (p) 2461-3961 (e) 2580-6335

Doi: 10.35569

Vol. 7 No. 1 Tahun 2021 Hal. 24-29

\title{
Biormatika:
}

Jurnal ilmiah fakultas keguruan dan ilmu pendidikan

http://ejournal.unsub.ac.id/index.php/FKIP/

\section{Enacting Copywriting Skills during Distance Internship: A Case Study at IQR Foundation}

\author{
Yessy Purnamasari ${ }^{1}$, Tri Puji Nur Uzlifah ${ }^{2}$ \\ English Department, Politeknik Negeri Bandung, Indonesia ${ }^{1,2}$ \\ yessy.purnamasari@polban.ac.id ${ }^{1}$,tri.puji.bing18@polban.ac.id ${ }^{2}$
}

\begin{tabular}{l} 
Info Artikel \\
\hline Sejarah Artikel: \\
Diterima Januari 2021 \\
Disetujui Februari 2021 \\
Dipublikasikan Februari \\
2021
\end{tabular}

\begin{abstract}
Distance internship rises as global pandemic Covid-19 starts in the beginning of 2020. It forces the higher education institution to remanage the rules of internship for second year students. As part of the regulation, the internship for Polban students was suggested to be done through distance methods. One of the NGOs that provide distance internships for English Department students is IQR Foundation. This study then investigates the enactment of students' copywriting skills and the challenges during distance internship. The data were collected by combining observation and study literature. The results show this distance internship enables students to apply copywriting skills through three enactments: composing script, creating English subtitles, and collaborating in news writing. Compared to the conventional one, distance internship leads to three main challenges: deciding concepts, using English as the language of communication, and handling the timeline. Distance internship, in many ways, has created many chances for students to grow up and to implement their knowledge in a new paradigm despite the pandemic as the boundary.
\end{abstract}

Keywords: copywriting, English, distance internship

\section{INTRODUCTION}

Field work practice (Praktik Kerja Lapangan or PKL in Bahasa Indonesia) or internship in short is one of unstructured subjects that should be done by students of Politeknik Negeri Bandung (Polban). In general, internship refers to a definition in which someone works for a nonpermanent position for the purpose of education, not employment (Weible, 2009). It becomes one of the requirements to graduate from campus. In English Department, the internship is done right after the fourth semester ends with 6 weeks duration. Through this program, students are given the real experience to know the reality of the working environment. (Narayanan, et.al., 2006). 
Previous studies on the field of internship have been conducted by many researchers. Most of the studies focus on digging the effectiveness of internship. By doing an internship, it enhanced the opportunity of employability as students have experienced the 'job market' in reality (Knouse \& Fontenot, 2008). It also raises students' value while applying for a job since most recruiters see the internship as the plus point of the applicants. In certain aspects, internship takes important part in giving the pertinent practice for students (Francis \& Alagas, 2017). By doing an internship, students will get such educational experience that are not thought during the lectures. It is true that students need practical activity that allow them to know the reality of working environment. Thus, to improve the learning proficiency of students during the internships, there should be great cooperation between companies and educational institutions to encourage, assist, and control students while completing their internship (Van den Bossche et al., 2012). To fill the gap, this study concerns on how internship can still be done although it is done remotely by analyzing the stages and the challenges as well.

Within the pandemic situation, the idea of distance internship then becomes a great answer. Studies on distance internship have shown that it can be done perfectly as the conventional one. Although the challenge arises, the process of supervising distance internship should applies the blended learning method which comes in three forms: direct visitation, online support system as well as video call usage (Skelton, 2014). Blended method somehow reduces the problems of distance, communication, or even dependency on the internship schedule. It allows both parties, company and intern, to set up the program more freely. Although distance internship has been continuously grown, but somehow it is not applicable for certain studies, for example in exercise and sport sciences degrees as it requires lots of physical activities (D'elia et al., 2019). This issue then should be overcome by the use of technology as the $21^{\text {st }}$ century learning method has been developed. Even in the supervising time, distance internship can be one of supportive choices to overcome distance and time barriers as students might find no difference between the face to face and the online one (Nelson et al., 2010).

Internship can be done by connecting students with governmental institution, private companies, or nongovernmental organization (NGO). IQR Foundation is one of NGOs in Indonesia which focuses on fourth aspects: literacy, education, leadership and sociopreneur. IQR aims to create the next generation and environment who have a high social care value; to maintain the volunteer to have active participation in building the nation; as well to fight for social and academic equity. In the academic year of 2020-2021, this NGO provides an internship program named MABAR (Magang Bareng) that hires university students to be actively involved in doing certain tasks.

In relation with the task, one of the skills applied for this internship is copywriting skill. Copywriting is a creative writing activity done by a copywriter. It aims to create easy to understand texts which can grab readers' attention. One example of applying copywriting skill is for the purpose of English promotional activities in printed and digital method (Reswari \& Diponegoro, 2020). In addition, as the technology has grown rapidly, the skill of 
copywriting in digital era forces copywriters to be able in emphasizing the best features of the products or services by the power of words ((Riesky, 2018)

In this internship program, the copywriting team has the following duties: a. producing texts for website and Instagram content which relate to four IQR Foundation pillars: literacy, education, leadership and sociopreneur. There are also other topics such as humanity, national disaster, or the latest viral issues which educate society both in national or international scopes. Those contents then be divided into 12 contents as seen on the following table:

Table 1 Type of content

\begin{tabular}{|c|c|c|}
\hline No & $\begin{array}{l}\text { Type of } \\
\text { Content }\end{array}$ & Explanation \\
\hline 1 & IQR Info & General information \\
\hline 2 & IQR Tips & General information \\
\hline 3 & IQR Sastra & $\begin{array}{l}\text { Literature figures, } \\
\text { works, and history }\end{array}$ \\
\hline 4 & $I Q R$ Kabar & $\begin{array}{l}\text { Good and bad news } \\
\text { about certain figures } \\
\text { both national and } \\
\text { international }\end{array}$ \\
\hline 5 & $\begin{array}{l}\text { IQR } \\
\text { Bahasa }\end{array}$ & Update on language \\
\hline 6 & IQR Quote & $\begin{array}{l}\text { Motivational quotes } \\
\text { based on IQR pillars }\end{array}$ \\
\hline 7 & IQR Baca & $\begin{array}{l}\text { Book } \\
\text { recommendation }\end{array}$ \\
\hline 8 & $\begin{array}{l}\text { IQR } \\
\text { Games }\end{array}$ & $\begin{array}{l}\text { Inspirational games } \\
\text { based on IQR pillars }\end{array}$ \\
\hline 9 & $\begin{array}{l}\text { IQR } \\
\text { Inspiratif }\end{array}$ & Inspirat \\
\hline 10 & IQR Opini & $\begin{array}{l}\text { Opinion based on } \\
\text { IQR pillars }\end{array}$ \\
\hline 11 & $\begin{array}{l}\text { IQR } \\
\text { Regional }\end{array}$ & $\begin{array}{l}\text { Report on IQR } \\
\text { regional activities }\end{array}$ \\
\hline
\end{tabular}

\begin{tabular}{|l|l|lr|}
\hline 12 & National & Greetings & on \\
& $\begin{array}{l}\text { Holiday } \\
\text { Greetings }\end{array}$ & $\begin{array}{l}\text { Indonesian } \\
\text { holidays }\end{array}$ & national \\
\hline
\end{tabular}

b. producing texts for Instagram feeds to support the IQR Foundation programs such as 'Rumah Baca', 'Campaign Donasi 10.000 Buku', 'Wakaf Alquran', 'Tebar Qurban di Afrika", 'Beasiswa Yatim Berprestasi' and 'IQR Talks".

c. creating timeline for Instagram feeds for a month. This activity is part of IQR Foundation efforts to keep the engagement with the followers.

\section{METHOD}

This research applies qualitative method. The participant for this study is the student from fourth semester who did the internship at IQR Foundation and took the role as the copywriter staff. To obtain the data, observation and literature study are done respectively. This research employs a case study approach at IQR Foundation. The case study aims purposively to acknowledge the enactment of applying copywriting skills as well as the challenges found by the young intern. In analyzing the data, the daily journal that the student filled is used as the main source of the analysis. This data then be classified to the stages and the challenges the student finds during the internship. Weekly supervision journal is also needed as the lecturer needs input from the field supervisor during the process of internship. The result of those analysis then be used to determine the relationship of distance internship with the educational institution, NGO, and students as the young intern. 


\section{RESULTS AND DISCUSSIONS}

Based on the analysis, there are three enactments of applying copywriting skill on distance internship as follows:

\section{a. Composing script}

Composing the script for websites and Instagram feeds needs high level of creativity. As the young intern, copywriting skills is very helpful to produce such creative content that is demanded by the editor. This requires the young intern to be innovative in choosing the diction as the audiences are general society.

\section{b. Producing English subtitles}

It has been mentioned before that most of the audiences of the content are Indonesian people. Thus, the ability to produce English subtitles which is easy to be understood is much needed. The skill of copywriting is then mixed with the ability to translate with communicative method in order to generate the subtitles.

\section{c. Collaborating in news writing}

As part of a big team, the young intern should be able to collaborate in news writing. This collaboration helps intern as well to work fast but effective. News writing requires copywriting skills and sufficient knowledge of certain issues.

Those enactments were the result of student's main job as the copywriter staff at IQR Foundation. Although it was done remotely, and mostly the communication between the field supervisor and the intern was done through WA chat, the job desks of being an 'online' copywriter staff has no difference if the intern works directly at the office. In composing the script, producing the subtitles, and collaborating with other team, student as the intern finds no difference with the offline internship as the duties and responsibilities are controlled by both the field supervisor and the lecturer.

If we compared to the conventional one, distance internship leads to three main challenges as follows:

\section{a. Deciding the concept}

The writer often finds it difficult in choosing the right content. The content accuracy affects the interest of IQR Foundation's followers on Instagram. Since copywriting requires the writer to write the contents daily, the writer often runs out of ideas in writing the contents. However, the writer is able to solve this problem by searching information on various sources. Since the audiences are mostly young people, the writer always follows the latest information on social media such as Instagram and Twitter in order to get the right content to write.

\section{b. using English as the language of communication}

Most of IQR Foundations followers on Instagram are Indonesian people. Accordingly, almost all contents are written in Bahasa Indonesia. English is not the first language for Indonesian people; therefore, the writer often finds difficulties in making content in English or related to English Department. Besides, the writer finds it difficult in determining the language style for a content. Most of IQR Foundation's followers on Instagram are young people; thus, the writer does not only have to use standard language based on KBBI but also easy to understand.

In order to solve this problem, the writer always tries to find opportunities to use English in writing contents. For instance, the writer always writes English subtitles for scripts in IGTV (Instagram TV). Besides, the writer makes a content of equivalent words and adapted words for IQR Bahasa content. 


\section{c. Handling the timeline}

Arranging the timeline for uploading contents is not easy for the writer. After the final draft has been made, the writer and her copywriting teammates have to submit it to the editing team. The process of editing a content requires a long time; hence, the schedule for uploading the content sometimes is not in accordance with the timeline which has been made by the copywriting team. To solve this problem, the writer always consults with the field supervisor to get suggestions or advice. The advice from the field supervisor helps the writer and the copywriting team a lot to resolve difficulties in arranging the timeline of uploading to IQR Foundation's Instagram.

Those three main challenges were the result of minimal contact between the field supervisor and student as the intern. In certain times, student feels hard to understand what is meant by the task given by the field supervisor. However, since it is the distance one, many ways can be done to overcome those challenges. The student itself becomes more creative in deciding the concept as she has more time to surf on the websites. In using English as the main language, the student finds no difficulty as she is from English Department. However, it becomes a challenge to use communicative English as the reader or follower of the social media are mostly Indonesian people. Lastly, the workflow that somehow becomes a challenge, especially in handling the timeline, is part of student's learning in managing responsibilities and maintaining good communication with other staff. In the end, distance internship is only a matter of location as the process, tasks, as well as the responsibilities are still the same with the offline one.

\section{CONCLUSIONS}

Distance internship is the real solution for students to be able to fulfill the requirement as well as to stay home during the pandemic. It also enables them to apply the knowledge they get from the class into the working environment. In specific, distance internship trains students' soft skills such as critical thinking, leadership, time management, networking, public speaking, and teamwork. These skills help students to grow and to give them the experience of working professionally.

During the internship at IQR Foundation, three enactments on applying copywriting skills are done by these activities: script composition, English subtitles creation, and news writing collaboration. By joining in copywriting team, students are managed to be able to communicate with larger team, cooperate with editing team, and connect with the content editor. In handling a task, students also get the chance to extend the network since there are lots of people joining the team. They get new enrichment from their senior regarding their experiences and expertise. In short, this sharing activity also advantages students to pass the challenges during the distance internship smoothly.

\section{REFERENCES}

D'elia, F., Cassese, F. P., \& D'isanto, T. (2019). Augmented, virtual and robotics reality for distance learning and internship in telematics Sport and Exercise Science degrees in Italy. Journal of Human Sport and Exercise, 14(June), S792-S796. https://doi.org/10.14198/jhse.2019.1 4.Proc4.41

Francis, R. S., \& Alagas, E. N. (2017). Satisfaction towards internship programme and future career 
development for students in private higher education institutions: A research note. Asia-Pacific Journal of Innovation in Hospitality and Tourism, 6(2), 69-74.

Knouse, S. B., \& Fontenot, G. (2008). Benefits of the business college internship: a research review. Journal of Employment Counseling, 45(2), 61-66. https://doi.org/10.1002/j.21611920.2008.tb00045.x

Nelson, J. A., Nichter, M., \& Henriksen, R. (2010). On-line supervision and face-to-face supervision in the counseling internship: An exploratory study of similarities and differences. Vistas 2010, January 2015.

http://www.counselingoutfitters.com /vistas/vistas10/Article_46.pdf

Reswari, G. P. A., \& Diponegoro, U. (2020). Writing in a digital context : designing digital copywriting. 3rd ICOLET 2019 Bangkok, June, 89-94. https://www.researchgate.net/profile/ Girindra_Reswari2/publication/3419 67114_WRITING_IN_A_DIGITAL _CONTEXT_DESIGNING_DIGIT AL_COPYWRITING_SYLLABUS _FOR_APPLIED_ENGLISH_STU DENTS/links/5edb87e24585152945 3ca870/WRITING-IN-A-DIGITALCONTEXT-DESIGNINGDIGITAL-COP

Riesky, R. (2018). A multimodal analysis of students' commercial copywriting. Advances in Social Science, Education and Humanities Research, 166(Prasasti), 257-261. https://doi.org/10.2991/prasasti18.2018 .49

Skelton, D. (2014). Blended learning and supervision of distance internship and project students. New Zealand
Association for Cooperative Education $2014 \quad$ Conference Proceedings, 23-26. https://doi.org/978-0-473-28382-7 Van den Bossche, P., Gijselaers, W. H., \& Milter, R. G. (2012). Learning at the crossroads of theory and practice: Research on innovative learning practices. Learning at the Crossroads of Theory and Practice: Research on Innovative Learning Practices, 1249. https://doi.org/10.1007/978-94007-2846-2

VK Narayanan, Paul OLK, C. F. (2006). Determinants of internship effectiveness: an exploratory model. Academy of Management Best Conference Paper, 634.

Weible, R. (2009). Are universities reaping the available benefits internship programs offer? Journal of Education for Business, 85(2), 5963.

https://doi.org/10.1080/0883232090 3252397 